\title{
Characterization and Impact of Curing Duration on the Compressive Strength of Coconut Shell Coarse Aggregate in Concrete
}

\begin{abstract}
Mei Yun Chin, ${ }^{\mathrm{a}}$ Md. Rezaur Rahman,,$*$ Kuok King Kuok, ${ }^{\mathrm{a}}$ Wai Yun Chiew, ${ }^{\mathrm{a}}$ and Muhammad Khusairy Bin Bakri ${ }^{b}$

Partial replacement with coconut shell coarse aggregates was studied as a means to produce lightweight coconut shell concrete (CSC). Coconut shell concrete is a structural grade lightweight concrete that has a lower self-load compared to the normal weight concrete (NWC), which allowed the production of larger precast units. An experimental study and analysis were conducted using different volume percentages of $0 \%, 10 \%, 30 \%$, $50 \%$, and $70 \%$ of coconut shell as coarse aggregates, to produce M30 (30 $\mathrm{MPa}$ ) grade concrete. The compressive strength of the NWC and CSC were obtained on the $7^{\text {th }}$ and $28^{\text {th }}$ day. The optimum results obtained for M30 grade concrete at $7^{\text {th }}$ and $28^{\text {th }}$ day of CSC were 34.2 and $38.6 \mathrm{MPa}$, respectively. In addition, the workability and weight-reduction were analyzed and compared with NWC. Scanning electron microscopy (SEM) with energy dispersive X-ray spectroscopy (EDS/EDX) and Fourier transform infrared spectroscopy (FTIR) were also used to investigate the structural morphology, chemical composition, and infrared functional groups of the concrete.
\end{abstract}

Keywords: Coconut; Compressive; Morphological; Chemical; Functional groups

Contact information: a: Faculty of Engineering, Computing and Science, Swinburne University of Technology Sarawak Campus, Jalan Simpang Tiga, 93400, Kuching, Sarawak, Malaysia; b: Faculty of Engineering, Universiti Malaysia Sarawak, Jalan Datuk Mohammad Musa, 94300, Kota Samarahan, Sarawak, Malaysia; *Corresponding author: rmrezaur@unimas.my

\section{INTRODUCTION}

A huge amount of waste coconut shells is produced in tropical countries, especially Malaysia, where the disposal of this agricultural waste contributes to high disposal in landfills. For the past few years, researchers have started to extensively study the feasibility of employing this agricultural waste as coarse aggregates in concrete, which produces a lightweight concrete, such as coconut shell concrete (CSC). The increase in the development of infrastructure, such as buildings and utilities around the world, are directly contributing to the increasing demand for construction materials. Concrete is the most widely used construction material for most major construction projects (Ahlawat and Kalurkar 2014). Concrete is the second most consumed material around the globe behind water with 7.23 billion tons of production each year (Meddah et al. 2010; Chandar et al. 2019). Typically, in concrete, around $60 \%$ to $75 \%$ of a concrete mixture has consisted of aggregates (Kanojia and Jain 2015). The need for gravels as coarse aggregates is expected to reach 2050 million metric tons by year 2020 (Kanojia and Jain 2017). Therefore, the future development involved sustainability and environmentally friendly materials. There 
is a demand for alternative aggregates as replacement for current conventional aggregates as sources for production of concrete.

Malaysia is stated as the $10^{\text {th }}$ highest coconut production country with annual production of 650,000 tons (Yun 2019). In Sarawak, Jabatan Pertanian Sarawak, the Sarawak Department of Agriculture (2009), reported that the land area with coconut production stands at approximately 24,000 hectares. This makes Sarawak the state with the most total coconut production area per hectare in Malaysia. Indirectly, many wastes would also be produced from coconut, either in the form of fiber, shell, trunk, etc. Therefore, the coconut shell waste plays a big potential role as a partial replacement material for the coarse aggregate. However, it can be used to produce structural lightweight concrete with lower density and better thermal insulation properties (Chandra 1996; Gunasekaran et al. 2017; Nadir and Sijatha 2017).

The constituents of the lightweight concrete are similar to those of normal weight concrete (NWC), except for the type of coarse aggregates (Basri et al. 1999). Today, it is also common that a lightweight aggregate is used for lightweight concrete manufacturing, such as sugarcane bagasse, ash, rice husk, oil palm hell, pumice, sawdust, and coconut shell (Basri et al. 1999). The coconut shell shows promising potential to be used as coarse aggregate, especially when it involves the costly replacement areas of conventional coarse aggregates. It has high toughness, durability, and abrasion resistance properties (Pappu et al. 2007; Nadir and Sijatha 2017). Moreover, the coconut shell replacement concrete has good strength properties, which show the densities of the concrete samples decrease as the percentage of the coconut shell replacement increases (Yerramala and Ramachandrudu 2012). The replacement of conventional coarse aggregate with coconut shell, which was $50 \%$ coconut shells replacement, reduced invariably approximately 10 to $15 \%$ of the concrete flexural strength, compared to the ordinary Portland cement (OPC) concrete (Yerramala and Ramachandrudu 2012; Shraddha et al. 2014).

To cast concrete slab, in the same ratios of $0 \%, 25 \%, 50 \%, 75 \%$, and $100 \%$, sawdust has been used to replace fine aggregate and palm kernel shells have been used to replace coarse aggregate (Olutoge 2010). The compressive strength and flexural strength of coarse aggregate showed that the $25 \%$ replacement produces low-stress lightweight slab (Olutoge 2010). However, the coarse aggregate reduced $7.43 \%$ cost per cubic meter (Olutoge 2010). Additionally, the lightweight concrete density was within the range of 1440 to $1900 \mathrm{~kg} / \mathrm{m}^{3}$, while normal concrete density was within the range of 2240 to $2400 \mathrm{~kg} / \mathrm{m}^{3}$ (Olutoge 2010). In contrast, the structural lightweight concrete usually has the compressive strength of more than $17 \mathrm{MPa}$. For structural applications, the concrete strength should be more than 17 $\mathrm{MPa}$, which may sometimes vary depending on the research, scope, specifications, conditions, and standard referred by the National Ready Mixed Concrete Association (2003).

In this research, the optimum replacement percentage of CSC using coconut shell waste as partial replacement of coarse aggregate with different replacement percentages was investigated. Therefore, to achieve the goal, the samples were cast, tested, and characterized using slump and compressive tests, scanning electron microscopy (SEM), energy dispersive X-ray spectroscopy (EDS/EDX), and Fourier transform infrared spectroscopy (FTIR). The strength of CSC is compared with the NWC also reported. 


\section{EXPERIMENTAL}

\section{Materials}

The materials used for this project consisted of sand as fine aggregate, gravels, coconut shells, OPC, and water. The OPC with CEM I 42.5N grade was obtained from Cahya Mata Sarawak (CMS) Cement Sdn. Bhd., Sarawak, Malaysia, which complied with the BS EN 197-1 (2011) standard, while the river sand, gravel, and coconut shells were obtained from a local supplier SK Hardware Sdn. Bhd. located in Kuching, Sarawak, Malaysia.

\section{Sample Preparation}

River sand was selected to be used as fine aggregate. It was sieved to pass through 4.75-mm particle size openings. The main elemental composition of coconut shell is carbon (C) and potassium oxide $\left(\mathrm{K}_{2} \mathrm{O}\right)$ (Leman et al. 2016). The coconut shells (CS) were used to replace coarse aggregates. The CS was crushed into coarse sizes between 5 and $20 \mathrm{~mm}$, as shown in Fig. 1.

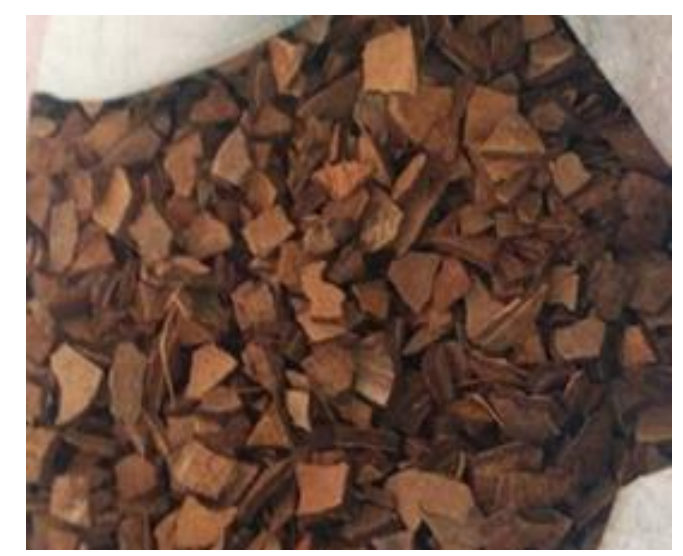

Fig. 1. Coarse aggregates of coconut shell

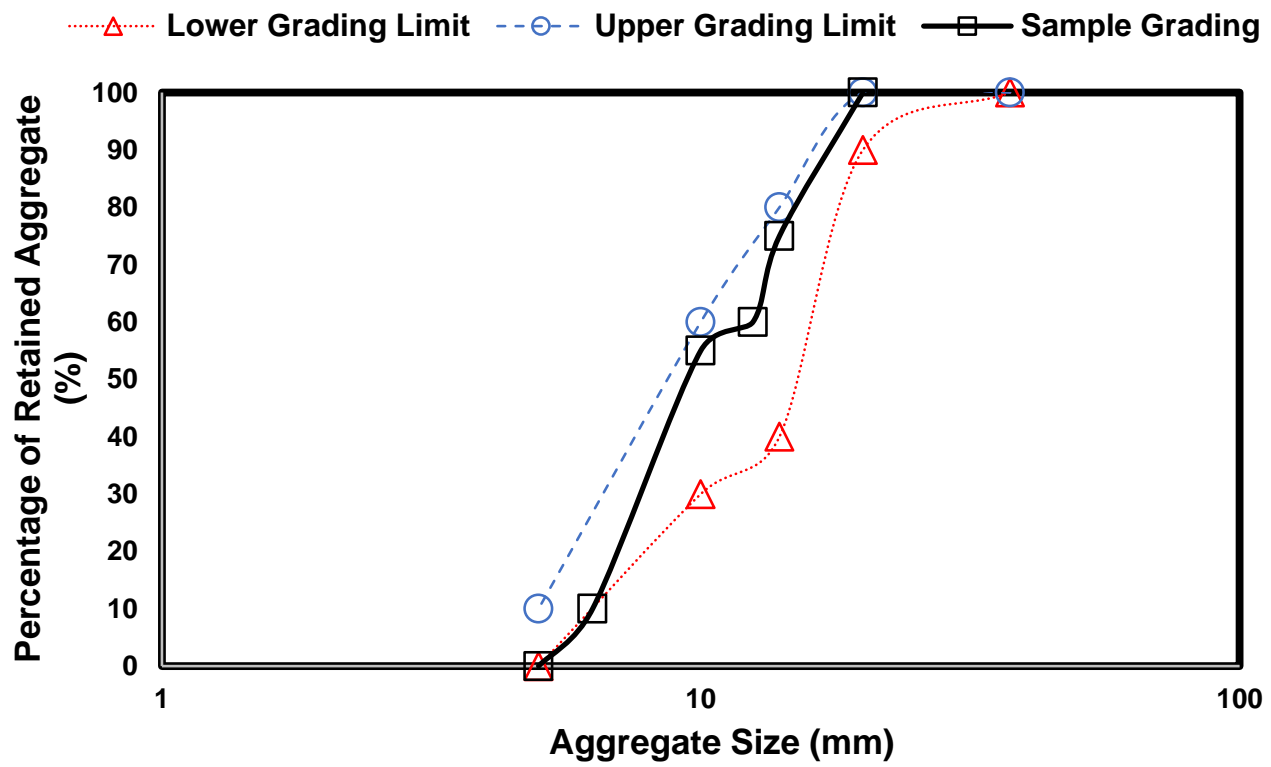

Fig. 2. The grading limit for both coconut shell and coarse aggregate 
Throughout the process, the fiber on the surface was removed from the coconut shells. The coconut shell aggregates were air-dried in a ventilated oven for 2 days at the temperature of $40{ }^{\circ} \mathrm{C}$ to remove excessive moisture, before being sieved again to separate the sizes. It was later kept in a dry storage, and prior to casting the required amount of coconut shell aggregates was measured and pre-soaked one day in advance to ensure the coconut shell aggregates were in a saturated surface dry (SSD) condition.

For NWC, gravels were selected as coarse aggregate, with the size range from 5 $\mathrm{mm}$ to $20 \mathrm{~mm}$. The gravel aggregates and coconut shells were sieved into the specific sieve ranges of $20 \mathrm{~mm}, 14 \mathrm{~mm}, 12.5 \mathrm{~mm}, 10 \mathrm{~mm}, 6.3 \mathrm{~mm}$, and $5 \mathrm{~mm}$. The limit percentage of mass passing each sieve size was determined by referring to the BS 882 (1992) and BS EN 12620 (2002) standards. Figure 2 shows the grading limit for both coconut shell and coarse aggregate.

\section{Mixture Proportion Design}

For the NWC, the concrete mix was designed according to IS 10262 (2019) and IS 456 (2019) standards. The M30 grade (30 MPa) was adopted for the concrete. The nominal proportion was used 1: 1.85: 3.19 (cement: fine aggregate: coarse aggregate) by volume with the water to cement ratio of 0.45 . A total of five different batches of concrete were designed, in which the concrete samples were cast with $0 \%, 10 \%, 30 \%, 50 \%$, and $70 \%$ replacement of coconut shells as coarse aggregates. Table 1 shows the schedule of specimen preparation.

Table 1. Schedule of Sample Preparation

\begin{tabular}{|c|c|c|c|c|c|}
\hline \multirow{2}{*}{$\begin{array}{c}\text { Batch } \\
\text { Number }\end{array}$} & \multirow{2}{*}{$\begin{array}{c}\text { Batch } \\
\text { Name }\end{array}$} & \multirow{2}{*}{$\begin{array}{c}\text { Percentage of } \\
\text { Coconut Shell (\%) }\end{array}$} & $\begin{array}{c}\text { Percentage of Coarse } \\
\text { Aggregate (\%) }\end{array}$ & \multicolumn{2}{|c|}{$\begin{array}{c}\text { Number of } \\
\text { Samples }\end{array}$} \\
\cline { 5 - 7 } & & & $7^{\text {th }}$ Day & $\mathbf{2 8}^{\text {th }}$ Day \\
\hline 1 & NWC & 0 & 100 & 3 & 3 \\
\hline 2 & CSC10 & 10 & 90 & 3 & 3 \\
\hline 3 & CSC30 & 30 & 70 & 3 & 3 \\
\hline 4 & CSC50 & 50 & 50 & 3 & 3 \\
\hline 5 & CSC70 & 70 & 30 & 3 & 3 \\
\hline
\end{tabular}

\section{Sample Fabrication, Workability Test, and Curing Condition}

In the casting process, OPC, river sand as fine aggregates, and gravels with and without coconut shells as coarse aggregates were evenly mixed using a concrete mixing drum. The water was added into the mixture, and the mixing was continued for 15 min. Part of the mixture was separated to run the slump cone test for the concrete workability according to BS EN 12350-2 (2019). The mixture was placed into the molds with three equal layers of compaction (mold dimension used was $100 \mathrm{~mm}$ x $100 \mathrm{~mm}$ x $100 \mathrm{~mm}$ ). It was carried out using a concrete poker vibrator to remove the entrapped air and avoid the segregation of the particles. After completion of concrete placement, the samples were left to dry in the lab for $24 \mathrm{~h}$ before demolding was carried out. The samples were then placed in a water tank filled with water to be cured up as shown in Table 1. The method to produce the concrete mixture was in accordance with the IS 10262 (2019) standard. The experimental work is shown in Fig. 3. The curing condition used is at room temperature and pressure with 7 and 28 days. 


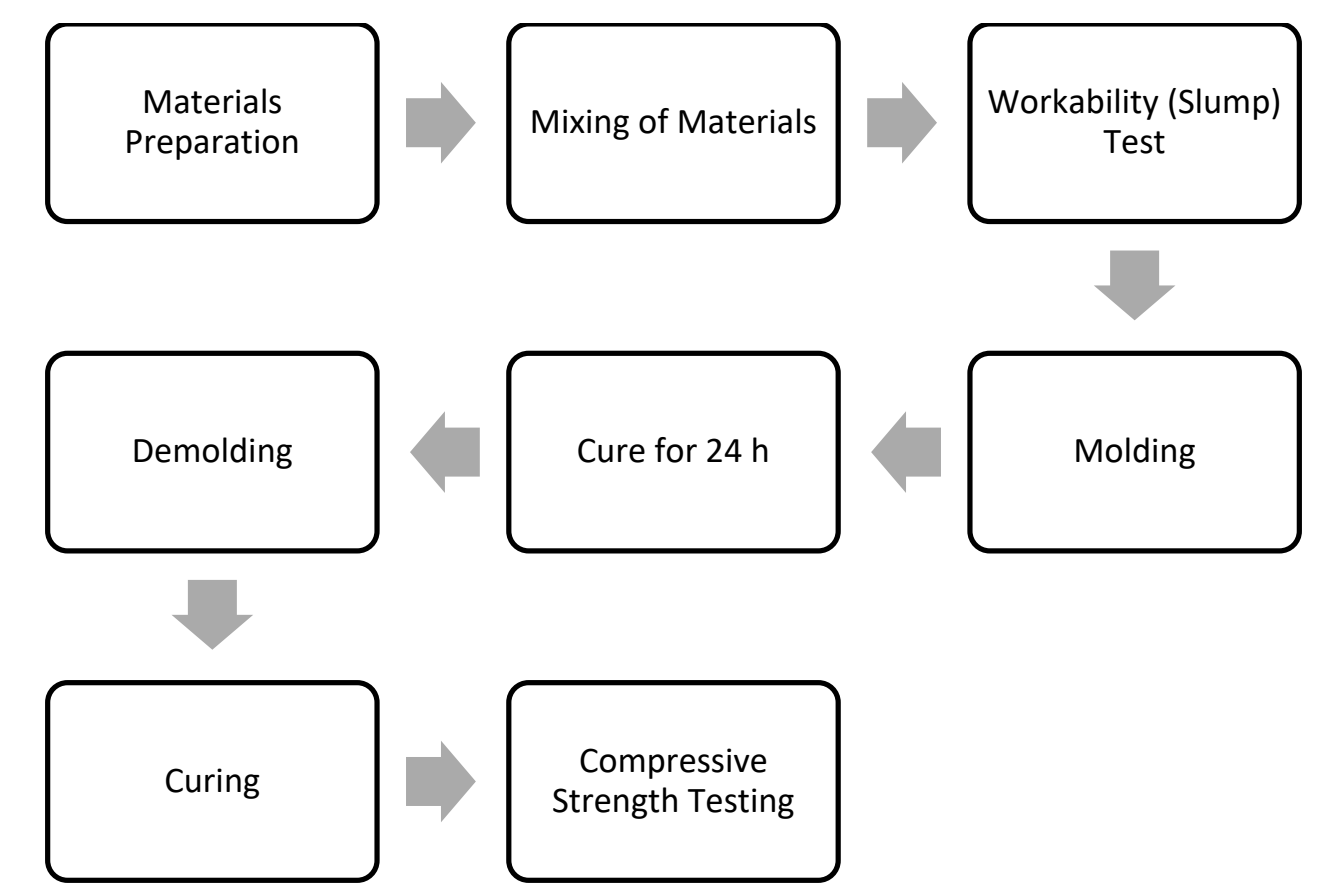

Fig. 3. Structure of experimental procedure

\section{Compressive Strength Test}

The compressive strength test was conducted in accordance with BS EN 196-1 (2016) using a Unit Test Autocon 2000 (Promat (HK) Ltd., Hong Kong). The load was applied gradually onto the samples at $2.4 \pm 0.2 \mathrm{kN} / \mathrm{s}$, during the compressive strength test until the specimens failed. Results obtained from concrete specimens of the same batch were averaged and recorded.

\section{Scanning Electron Microscopy and Energy Dispersive X-ray Spectroscopy}

Scanning electron microscopy and energy dispersive X-ray/spectroscopy were conducted according to ASTM C1723-16 (2016) and ASTM E1508-12 (2019) standards, respectively. A Hitachi TM4000Plus Tabletop Microscope with a Quantax75TM series energy dispersive X-ray spectrometer (Hitachi Ltd., Tokyo, Japan) was used for the SEM and EDX/EDS analyses of the samples to investigate the composition, surface structure, and size. A magnification of 1000x was utilized to observe the samples on a selected few random surface areas on the samples. The automated software scanned and analyzed the elemental composition percentages of the samples. It was repeated numerous times for each sample at different points, whereas the most representative results were selected and recorded.

\section{FTIR}

A Fourier-transform infrared spectroscopy (IRAffinity-1, Shimadzu Corporation, Kyoto, Japan) was used for the FTIR analysis of the NWC and CSC samples. Fouriertransform infrared spectroscopy was conducted according to the ASTM E168-16 (2016) and ASTM E1252-98 (2013) standards for qualitative and quantitative analysis. The spectrum scanning was conducted in the wavenumber range of 4000 to $400 \mathrm{~cm}^{-1}$ for each sample. Fourier-transform infrared spectroscopy utilized the infrared spectrum transmittance and absorption of the samples to develop a unique molecular fingerprint 
spectrum. The test was repeated numerous times for each sample, and the most representative results were selected.

\section{RESULTS AND DISCUSSIONS}

\section{Workability (Slump) Analysis}

The slump test results for each batch of concrete are shown in Fig. 4. It was observed that as the percentage replacement of the coconut shell increased, the workability of the mixtures increased. For the NWC mixtures, it exhibited the lowest slump value, which was around $10 \mathrm{~mm}$. The mixture was relatively dry and required the help of a concrete poker vibrator to achieve proper compaction, as shown in Fig. 5a. The reason behind this is due to the hydration of excessive water in the cement.

Slump values of 10 to $45 \mathrm{~mm}$ were observed for CS concrete mixtures (CSC10 through CSC70), which can be classified between low to medium workability. The highest slump was spotted at the CS replacement of 70\% (CSC70), as shown in Fig. 5b. This observation showed that the percentage of CS replacing the coarse aggregate was proportional to the slump value of the mixtures. The workability of CS concrete was higher than the OPC concrete due to the smooth surface on one side of the shells compared to natural conventional aggregates (Gunasekaran et al. 2012; Shahidan et al. 2016). It was also observed that the inner dry coconut shell contains a waxy thin layer of dried white flesh meat (solid endosperm), which indirectly contributed to the smooth surface. However, the rough texture on the conventional aggregates exhibited higher friction and segregation tendency. The CS aggregates had a small surface area, which was not covered with wax or oil compared to the conventional aggregates that require a lesser amount of water for the lubricating effect. Thus, this result showed the better workability forces (Roa et al. 2015). Moreover, over slump may create less compression strength concrete, as it does not reach a stable optimized mixture.

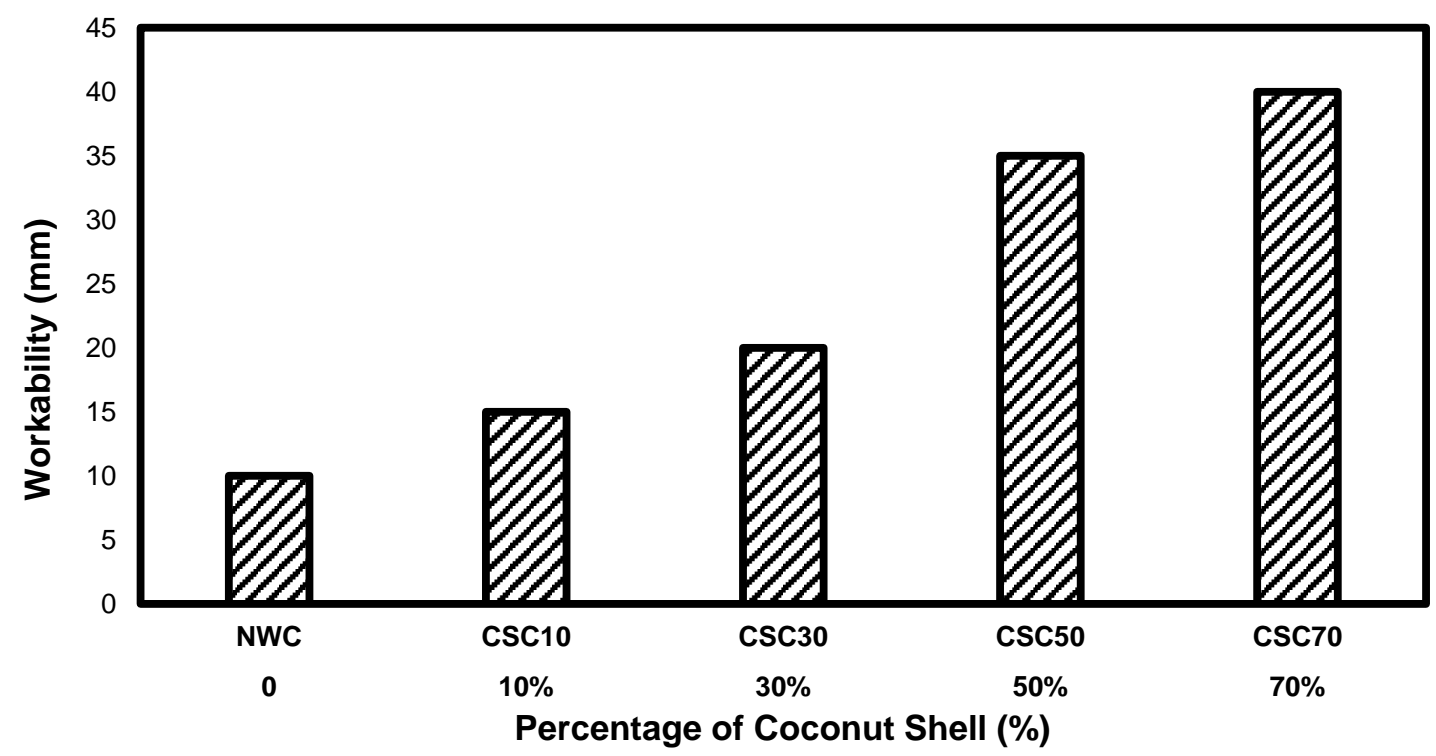

Fig. 4. Workability at different percentage of CS concrete samples 


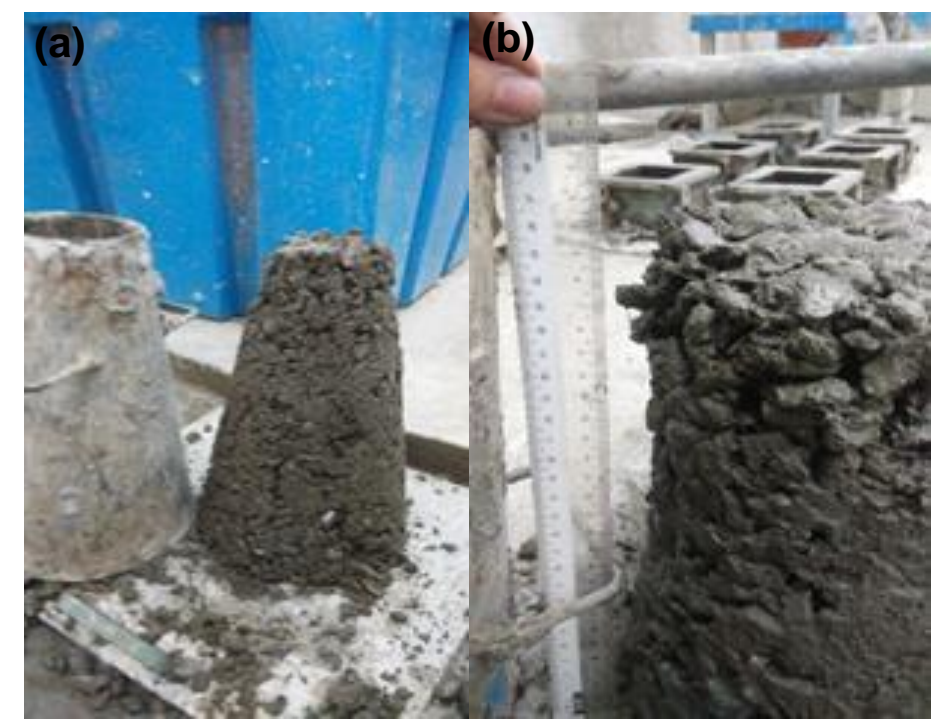

Fig. 5. Observed workability for (a) NWC and (b) $70 \%$ of CS concrete

\section{Compressive Strength Analysis}

The compressive strength for the NWC and CSC on the $7^{\text {th }}$ day and the $28^{\text {th }}$ day are shown in Fig. 6. Based on Fig. 6, the compressive strength of concrete decreased as the percentage of CS replacement increased. The early strength age of $10 \%$ of CSC was able to achieve $34.2 \mathrm{MPa}$ at the $7^{\text {th }}$ day and 44.7 MPa at the $28^{\text {th }}$ day. The decrease in strength was noticeable, as the CS replacement was over $30 \%$ of CSC for both the $7^{\text {th }}$ day compressive strength and the $28^{\text {th }}$ day compressive strength, respectively.

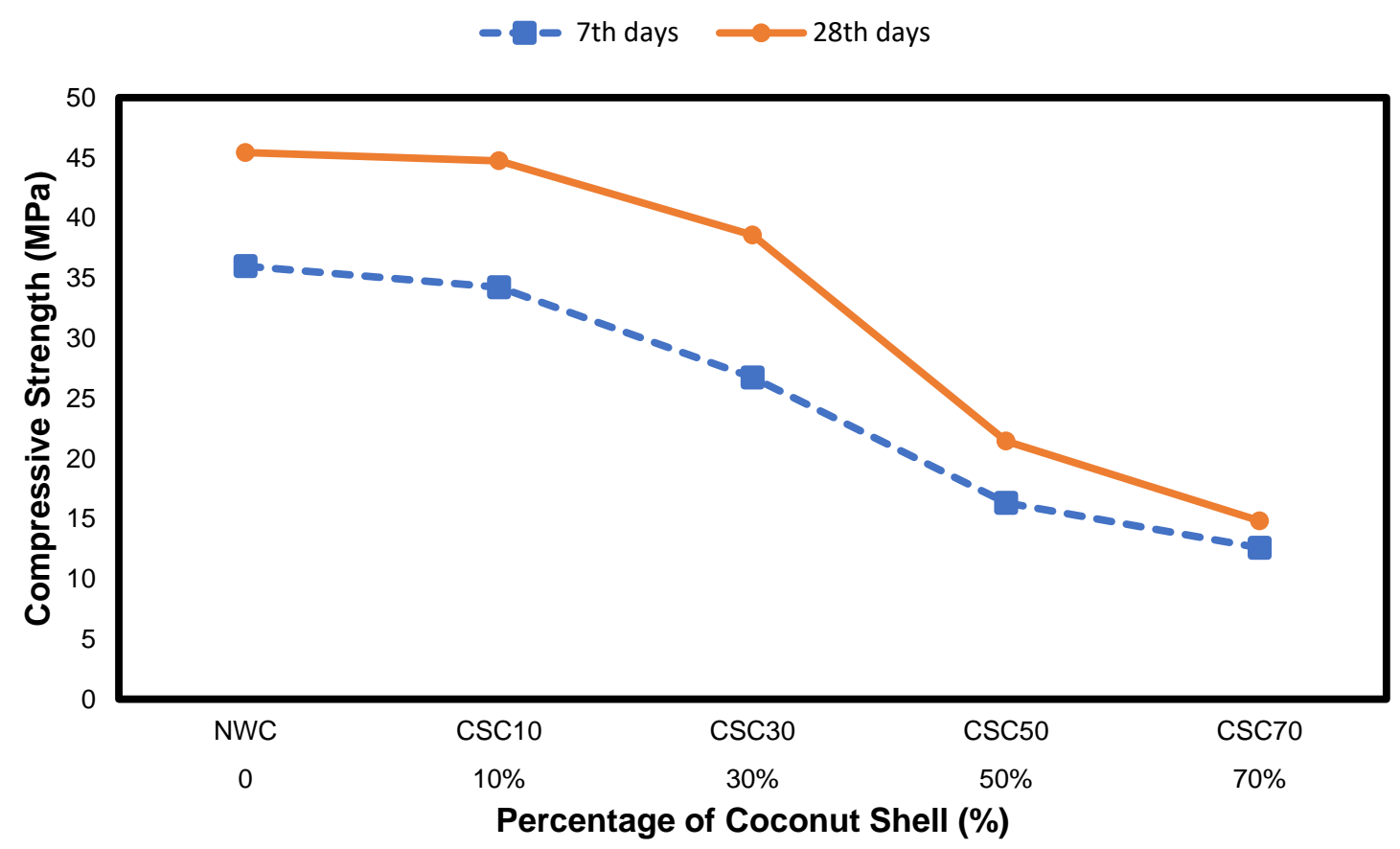

Fig. 6. Compressive strength of change in the percentage of coconut shell as replacement of coarse aggregates in concrete 


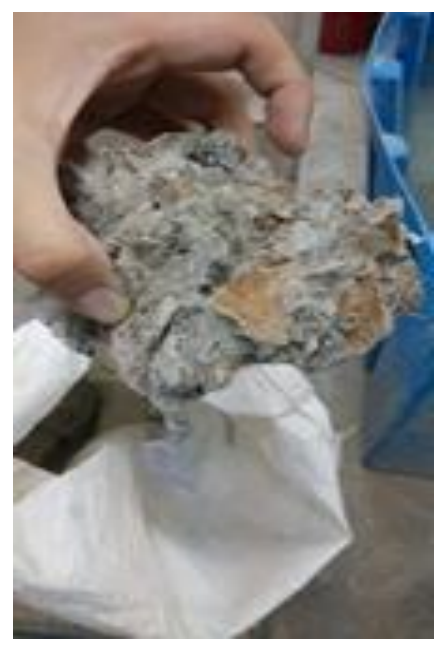

Fig. 7. Typical failure mode for the $7^{\text {th }}$ day of the $50 \%$ CSC (CSC50) sample due to coconut shells separation from the cement paste

On the $7^{\text {th }}$ day, the compressive strength results showed that the CSC with more than $30 \%$ (CSC30 and above) replacement level failed to maintain and decreased its strength due to an insufficient bond between aggregates and cements. While the early strength age showed that concrete depends on the cement mixture strength, when it was reached at the later age, the concrete strength increased due to the curing effects between aggregates and paste, strength of the paste, and strength of the aggregates (Roa et al. 2015). This was observed from the experiment on the specimen's failure under the compressive strength test due to the separation of coconut shell aggregates from the cement paste as shown in Fig. 7.

The $28^{\text {th }}$ day average compressive strength for the $10 \%$ of CSC was $44.7 \mathrm{MPa}$, which was almost comparable to the NWC compressive strength of $45.4 \mathrm{MPa}$. The CSC within $10 \%$ to $30 \%$ coarse aggregate replacement using coconut shell aggregates can be used for structural applications, as the compressive strength had satisfied the minimum requirement of $30 \mathrm{MPa}$. For non-load bearing applications, CS concrete with $50 \%$ coarse aggregate replacement using coconut shell aggregates can be considered as lightweight concrete, as the $28^{\text {th }}$ day compressive strength with $21.4 \mathrm{MPa}$ satisfied the minimum requirement for lightweight concrete at $17 \mathrm{MPa}$ (National Ready Mixed Concrete Association 2003). The interlocking action between the smooth interface of coconut shell aggregates and the cement was weaker compared to the interlocking between the rough interface of gravel and cement. This was due to the smooth inner dry surface of the coconut, which had a slippery surface. Thus, the bonding action between coconut aggregates was not as effective as the conventional gravel aggregates and it leads to lower compressive strength (The Constructor 2017).

\section{Self-weight Reduction}

There are advantages to using coconut shell aggregates to replace the conventional aggregate for weight reduction. The self-weight reductions for $10 \% \mathrm{CSC}$ was $3.75 \%, 30 \%$ CSC was $8.69 \%, 50 \%$ CSC was $12.7 \%$, and $70 \%$ CSC was $23.37 \%$, as shown in Fig. 8. The CSC with 50\% coarse aggregate replacement using coconut shell aggregates had an average weight of $2095 \mathrm{~kg} / \mathrm{m}^{3}$, which was close to the density of lightweight concrete. The decrease in self-weight was due to the density of coconut shell aggregates, which was 550 
$\mathrm{kg} / \mathrm{m}^{3}$ compared to the conventional aggregates with $1162 \mathrm{~kg} / \mathrm{m}^{3}$ (Sabih et al. 2016). Thus, the results showed that the weight reduction was directly related with the increment in the percentage of coconut shells as a coarse aggregate replacement. The reduction in selfweight of the concrete brought benefits for the construction of a building structure, as this can lead to the reduction of the required load capacity of the foundation, and subsequently, the reduction of foundation size, and cost saving.

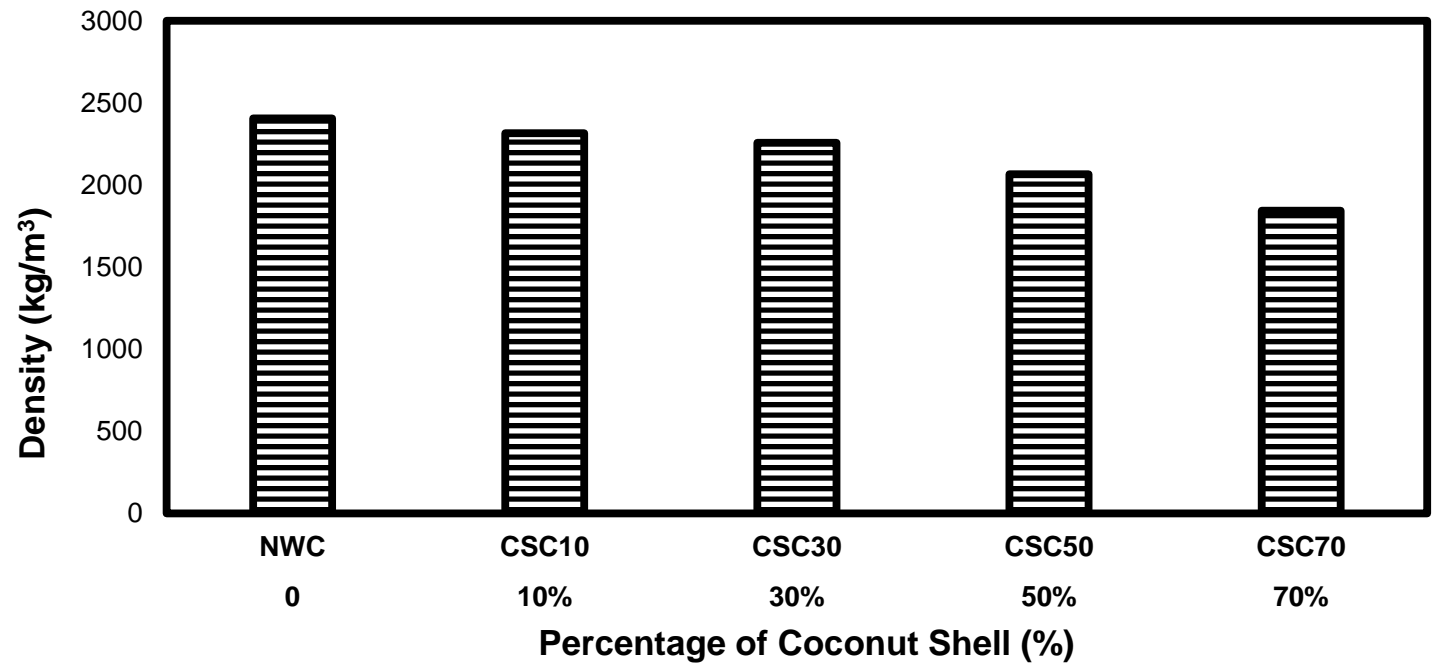

Fig. 8. Density versus change in the percentage of coconut shell aggregates as coarse aggregate replacement in concrete

\section{Scanning Electron Microcopy}

The SEM images of a selected area of compacted microstructure of CS concrete are shown in Figs. 9a, b, and c. Figure 9 also shows the topological structure of concrete structure, which is due to the proper mixture process, while investigating the effect of curing and hydraulic reactivity on concrete surface (Gunasekaran et al. 2012, 2015; Traore et al. 2017). Figure 9a shows the few traces of the inner-smooth side of the coconut shell, which was still in original form. It shows that one side of the coconut shell bonded with the cement paste (which is the outer side of the coconut shell), while the other side did not properly bond (which is the inner-dry smooth side of the coconut shell) (Gunasekaran et al. 2012, 2015; Traore et al. 2017). This smooth area of coconut shell contributed to the failure of the concrete.

From Fig. 9b, the SEM images show the flakes of cement and sand mixtures. These globular flakes sometimes happen due to improper chemical reactivity between the cement and sand due to a lack of water or dehydration of water (Samiei et al. 2017; Chandar et al. 2018). Figure 9c shows less presence of needle shape ettringite particle as well as the platy shape of Portlandite particles on the cement surface (Shubbar et al. 2020). This indicated that the cementitious bond almost covered the sample with less noticeable pore voids, which creates a dense and coherent microstructure, after a longer curing period (Henrist et al. 2003; Wu et al. 2008; Kumar et al. 2009; Shubbar et al. 2020). The harmonization is important for a proper bond between each substance in concrete, whereas the proper mixture and chemical reactivity influenced the compressive strength and workability (Biernacki et al. 2017). 


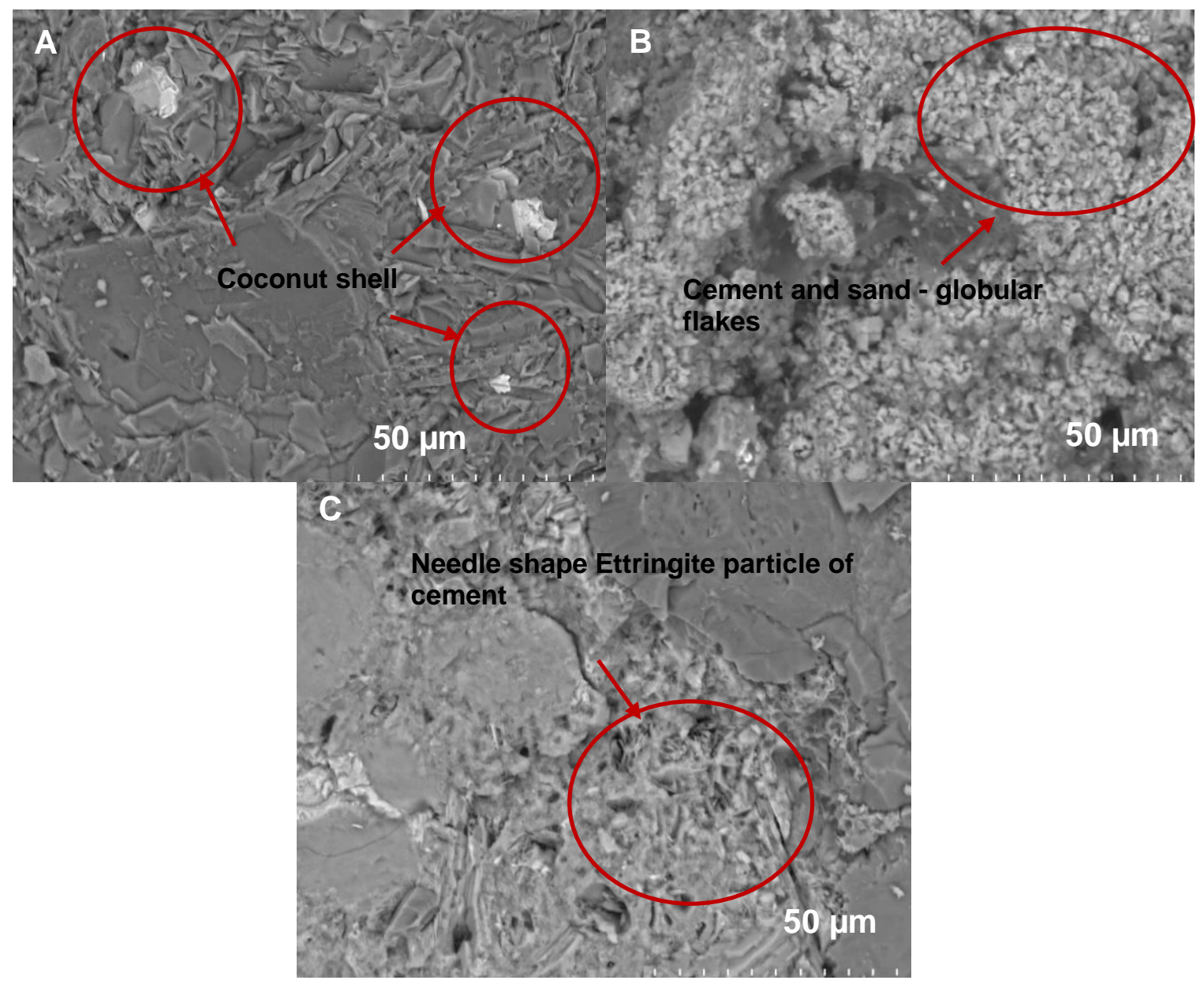

Fig. 9. SEM images of CS concrete at (a) break structure, (b) area where most of it was covered with sand and Portland cement, and (c) all parts of the mixture

\section{Energy Dispersive X-ray Spectroscopy Analysis}

The EDS/EDX elemental analysis for CS concrete is shown in Table 2, while Fig. 10 shows the spectrum graph in correlation with the data in Table 2. According to Table 2, the elements present in the samples were oxygen $(\mathrm{O})$, silicon $(\mathrm{Si})$, aluminum $(\mathrm{Al})$, iron $(\mathrm{Fe})$, natrium $(\mathrm{Na})$, carbon $(\mathrm{C})$, calcium $(\mathrm{Ca})$, magnesium $(\mathrm{Mg})$, and potassium $(\mathrm{K})$. From Fig. 10 and Table 2, it is shown that the oxygen mass percentage had the highest content, followed by silicon, while the other remaining elements remained low in mass percentage. This was due to the chemical reaction that occurred during the mixing of the paste mixture and hydraulic processing, which creates possible oxides like $\mathrm{CaCO}_{3}, \mathrm{Fe}_{2} \mathrm{O}_{3}, \mathrm{Al}_{2} \mathrm{O}_{3}, \mathrm{CaO}$, $\mathrm{MgO}, \mathrm{MgO}, \mathrm{K}_{2} \mathrm{O}, \mathrm{P}_{2} \mathrm{O}_{5}, \mathrm{Na}_{2} 0$, and $\mathrm{SiO}_{2}$ (Matschei et al. 2007; Wassilkowska et al. 2014; Yaacob et al. 2015; Askarinejad and Rahbar 2017).

The presence of $\mathrm{CaCO}_{3}$ helps to increase the early strength of the CS concrete, due to the accelerator effect and high rate of hydration, which hardens the concrete quicker (Matschei et al. 2007; Yaacob et al. 2015). At a matured age, the concrete with the $\mathrm{CaCO}_{3}$ addition, exhibited lower strength as compared with concrete without $\mathrm{CaCO}_{3}$, but still within the target strength (Matschei et al. 2007; Yaacob et al. 2015). It was noticeable that the proper mixing ratio and chemical substance was used to create the proper reactivity in concrete. However, the strong bonding between each substance used in the mixture is shown through the morphological images by SEM in Fig. 9. It shows that the presence of 
carbon was also due to content from coconut. In addition, it has been reported by few researchers that the elemental composition of coconut shell contained about $29.4 \%$ lignin, $27.7 \%$ pentosans, and $26.6 \%$ cellulose (Husseinsyah and Mostapha 2011, Adebakin et al. 2018; Ikumapayi and Akinlabi 2019).

Table 2. EDS Element Composition for CSC10 Concrete

\begin{tabular}{|c|c|c|c|c|c|}
\hline Element & $\begin{array}{c}\text { Atomic } \\
\text { No. }\end{array}$ & $\begin{array}{c}\text { Mass } \\
\text { Normal (\%) }\end{array}$ & $\begin{array}{c}\text { Atom } \\
\text { (\%) }\end{array}$ & $\begin{array}{c}\text { Absolute Error (\%) } \\
\text { (1 sigma) }\end{array}$ & $\begin{array}{c}\text { Relative Error (\%) } \\
\text { (1 sigma) }\end{array}$ \\
\hline $\mathrm{O}$ & 8 & 50.72 & 63.50 & 6.87 & 11.89 \\
\hline $\mathrm{Si}$ & 14 & 25.74 & 18.36 & 1.25 & 4.26 \\
\hline $\mathrm{Al}$ & 13 & 7.43 & 5.51 & 0.42 & 5.02 \\
\hline $\mathrm{Fe}$ & 26 & 4.01 & 1.44 & 0.19 & 4.06 \\
\hline $\mathrm{Na}$ & 11 & 3.21 & 2.80 & 0.26 & 26.61 \\
\hline $\mathrm{C}$ & 6 & 2.85 & 4.75 & 0.86 & 4.24 \\
\hline $\mathrm{Ca}$ & 20 & 2.53 & 1.27 & 0.12 & 6.93 \\
\hline $\mathrm{Mg}$ & 12 & 1.84 & 1.51 & 0.15 & 4.87 \\
\hline $\mathrm{K}$ & 19 & 1.68 & 0.86 & 0.09 & \\
\hline \multicolumn{2}{r}{ Total } & $100 \%$ & $100 \%$ & & \\
\hline
\end{tabular}

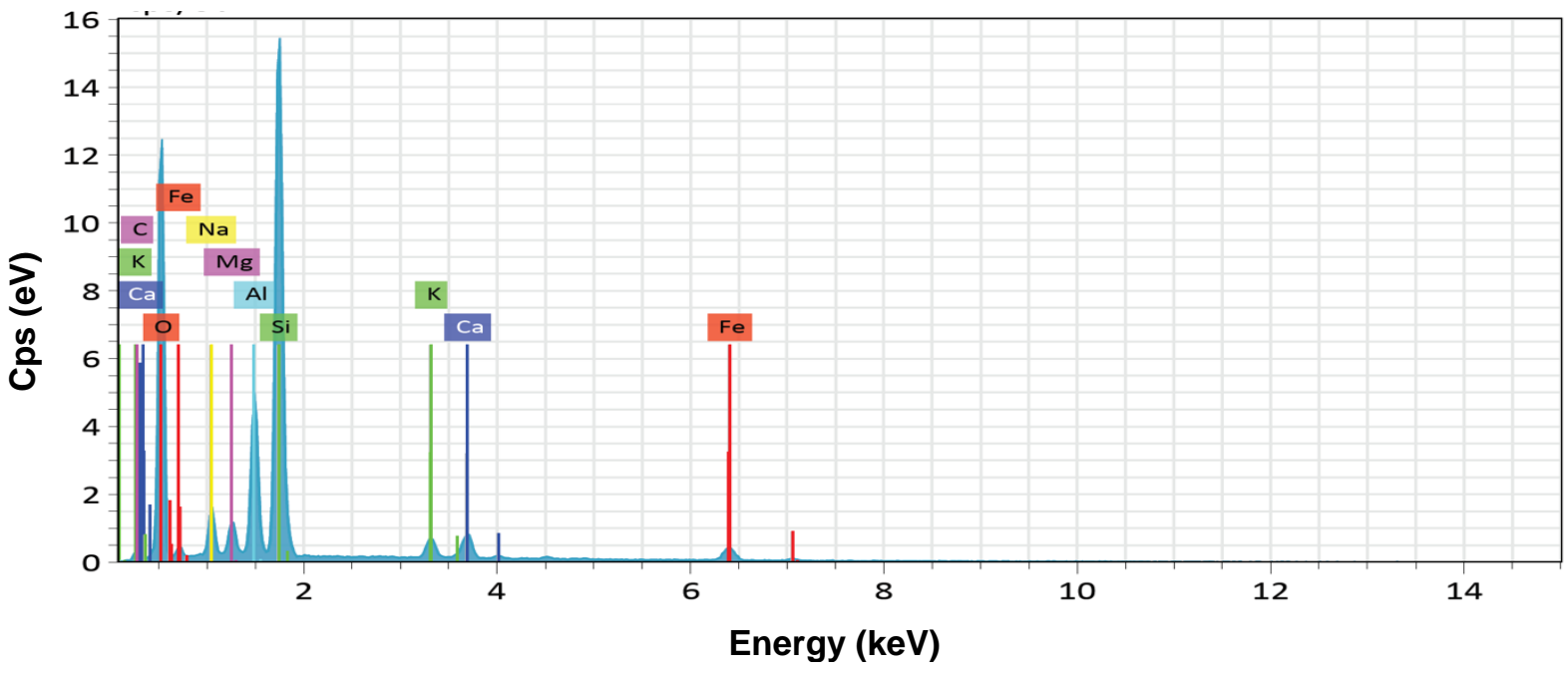

Fig. 10. EDS spectrum graph for CS concrete

\section{FTIR Analysis}

Figures 11 (a) and (b) show the FTIR spectrum images for the NWC and CSC. The three sharp peaks at $3847.99,3736.12$, and $3643.53 \mathrm{~cm}^{-1}$ for NWC, and $3844.13,3738.05$, and $3628.10 \mathrm{~cm}^{-1}$ for CSC are assigned to the $\mathrm{O}-\mathrm{H}$ stretching of $\mathrm{Ca}(\mathrm{OH})_{2}$ formed (Bensted 1976; Dutta et al. 1995; Oriol and Pera 1995; Yousuf et al. 1995; Trezza 2007; Lazim et al. 2015). For the coconut shell, O-H stretching usually is related to the hydroxyl group (Lazim et al. 2015). In NWC, the wide band that was observed in the region to $2700 \mathrm{~cm}^{-1}$ was due to the symmetric and asymmetric stretching of the $\mathrm{O}-\mathrm{H}$ vibrator of the water molecules (Bensted 1976; Dutta et al. 1995; Oriol and Pera 1995; Yousuf et al. 1995; Trezza 2007; Lazim et al. 2015). However, in CSC, there were many smaller peaks along the broadband due to $\mathrm{CH}$ stretches, which caused vibration of $\mathrm{CH}, \mathrm{CH}_{2}$, and $\mathrm{CH}_{3}$, groups of the coconut shell (Trezza 2007; Lazim et al. 2015). The sharp peak intensity at 2175.70 $\mathrm{cm}^{-1}$ and $2013.68 \mathrm{~cm}^{-1}$ for NWC increased in CSC at 2169.92 and $2023.33 \mathrm{~cm}^{-1}$, which was due to $\mathrm{C}=\mathrm{C}$ stretching vibration, which allowed strong harmonized mixtures in the 
concrete due to increase in curing duration (Trezza 2007). The small broadband at approximately 1759.08 and $1672.28 \mathrm{~cm}^{-1}$ for NWC, and 1853.59 and $1697.36 \mathrm{~cm}^{-1}$ was the deformation mode $\mathrm{H}-\mathrm{O}-\mathrm{H}$ of the molecular water absorbed (Trezza 2007). The bands of 1386.82 and $1091.71 \mathrm{~cm}^{-1}$ for NWC and $1398.39 \mathrm{~cm}^{-1}$ for CSC were attributed to $\mathrm{CH}$ stretching (Trezza 2007). The presence of $\mathrm{CaCO}_{3}$ was attributed to the atmospheric $\mathrm{CO}_{2}$ during curing time. The main characteristic of the hydrated sample was shown by the stretching mode $\mathrm{Si}-\mathrm{O}$ at $854.47 \mathrm{~cm}^{-1}$ in the NWC. According to the finding, it was demonstrated that $\mathrm{SiO}_{4}{ }^{4-}$ was present in both NWC and CSC, respectively (Bensted 1976; Dutta et al. 1995; Oriol and Pera 1995; Yousuf et al. 1995; Trezza 2007; Lazim et al. 2015).

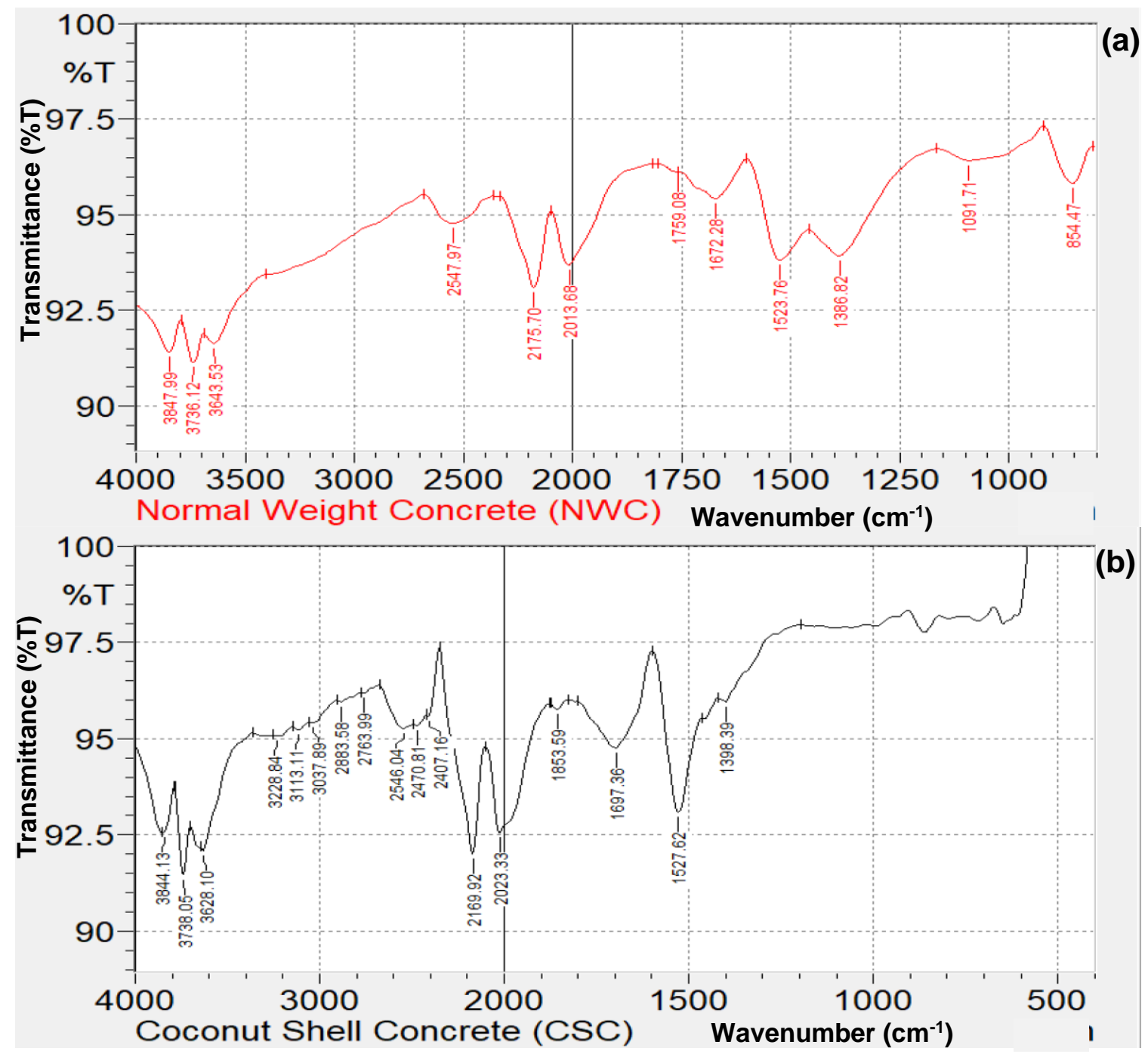

Fig. 11. The FTIR images for (a) NWC and (b) CSC samples 


\section{CONCLUSIONS}

1. The effect of utilizing coconut shells waste as coarse aggregate in concrete materials and its applications were investigated. Various benefits can be brought by using coconut shell (CS) as partial replacement for coarse aggregate in concrete such as weight reduction of concrete structures, especially on the pre-casting of larger units.

2. In addition, the coconut shells show a potential to replace the fast depleting natural coarse aggregate. Based on the experimental observations, the workability of the concrete mixture increased as the amount of coconut shell as coarse aggregates increased. The $28^{\text {th }}$ day compressive strength of the CS concrete with $30 \%$ of coconut shell was $38.6 \mathrm{MPa}$, which satisfied the structural application requirement according to international concrete standard.

3. In addition, it achieved acceptable workability with $20 \mathrm{~mm}$ slump. The CS concrete with $50 \%$ coconut shell as coarse aggregates replacement exhibited $21.45 \mathrm{MPa}$ of compressive strength at the $28^{\text {th }}$ day under full water curing, which satisfied the requirement for structural lightweight concrete at $17 \mathrm{MPa}$. The average self-weight of CSC with 50\% coconut shell as a coarse aggregates replacement also fell within the criteria of structural lightweight concrete.

4. The self-weight reduction of CSC was noticeable for the concrete structure, which reduced the required load capacity of the foundation. The surface morphology of the concrete was well mixed. However, the inner side of the coconut shell was not properly bonded with the cement paste due to the surface being covered with wax.

5. The EDS/EDX analysis showed the traces element, which create proper bonding with CS, cement, gravel, sand, and water. These chemical compositions correlated the impact of the compressive strength results. The CSC showed the similar compressive strength properties to the NWC, while mixing ratios and replacement percentages can be carried out before CSC can be utilized in building construction.

\section{ACKNOWLEDGMENTS}

The authors are grateful for the support of the Universiti Malaysia Sarawak in Kota Samarahan, Sarawak, Malaysia (UNIMAS).

\section{REFERENCES CITED}

Adebakin, I. H., Gunasekaran, K., and Annadurai, R. (2018). "Mechanical properties of self-compacting coconut shell concrete blended with fly ash," Asian Journal of Civil Engineering 20(4), 113-124. DOI: 10.1007/s42107-018-0091-7

Ahlawat, D., and Kalurkar, L. G. (2014). "Coconut shell as partial replacement of coarse aggregate in concrete," IOSR Journal of Mechanical and Civil Engineering 4(1), 6164.

Askarinejad, S., and Rahbar, N. (2017). "Effects of cement-polymer interface properties on mechanical response of fiber-reinforced cement composites," Journal of 
Nanomechanics and Micromechanics 7(2), Article ID 04017002. DOI:

10.1061/(ASCE)NM.2153-5477.0000119

ASTM C1723-16 (2016). "Standard guide for examination of hardened concrete using scanning electron microscopy," ASTM International, West Conshohocken, PA, USA.

ASTM E168-16 (2016). "Standard practices for general techniques of infrared quantitative analysis," ASTM International, West Conshohocken, PA, USA.

ASTM E1252-98 (2013). "Standard practice for general techniques for obtaining infrared spectra for qualitative analysis," ASTM International, West Conshohocken, PA, USA.

ASTM E1508-12 (2019). "Standard guide for quantitative analysis by energy-dispersive spectroscopy," ASTM International, West Conshohocken, PA, USA.

Basri, H. B., Mannan, M. A., and Zain, M. F. M. (1999). "Concrete using waste oil palm shells as aggregate," Cement and Concrete Research 29(4), 619-622. DOI:

10.1016/S0008-8846(98)00233-6

Bensted, J. (1976) "Uses of Raman spectroscopy in cement chemistry," Journal of the American Ceramic Society 59(3-4), 140-143. DOI: 10.1111/j.11512916.1976.tb09451.x

Biernacki, J. J., Bullard, J. W., Sant, G., Brown, K., Glasser, F. P., Jones, S., Ley, T., Livingston, R., Nicoleau, L., Olek, J., et al. (2017), "Cements in the $21^{\text {st }}$ century: Challenges, perspectives, and opportunities," Journal of the American Ceramic Society 100(7), 2746-2773. DOI: 10.1111/jace.14948

BS 882 (1992). "Specification for aggregates from natural sources for concrete," British Standard Institution, London, England.

BS EN 196-1 (2016). "Methods of testing cement. Determination of strength," British Standard Institution, London, England.

BS EN 197-1 (2011). "Cement, composition, specifications and conformity criteria for common cements," British Standard Institution, London, England.

BS EN 12350-2 (2019). "Testing fresh concrete. Slump test," British Standard Institution, London, England.

BS EN 12620 (2002). “Aggregates for concrete,” British Standard Institution, London, England.

Chandar, S. P., Gunasekaran, K., Satyanarayanan, K. S., and Annadurai, R. (2018). "Study on some durability properties of coconut shell concrete with quarry dust," European Journal of Environmental and Civil Engineering 24(6), 709-723. DOI: 10.1080/19648189.2017.1418435

Chandar, S. P., Gunasekaran, K., Priya, V. K., and Ganapathyramasamy, N. (2019). “An experimental investigation on partial replacement of sand by ceramic grains in coconut shell concrete," Rasayan Journal of Chemistry 12(2), 659-665. DOI: 10.31788/RJC.2019.1225227

Chandra, S. (1996). Waste Materials Used in Concrete Manufacturing, William Andrew Publishing, Norwich, NY, USA, pp. 1-672.

Dutta, D. K., Bordoloi, D., and Borthakur, P. C. (1995). "Hydration of Portland cement clinker in the presence of carbonaceous materials," Cement and Concrete Research 25(5), 1095-1102. DOI: 10.1016/0008-8846(95)00104-K

Gunasekaran, K., Annadurai, R., and Kumar, P. S. (2012). "Long term study on compressive and bond strength of coconut shell aggregate concrete," Construction and Building Materials 28(1), 208-215. DOI: 10.1016/j.conbuildmat.2011.08.072 
Gunasekaran, K., Chandar, P. S., Annadurai, R., and Satyanarayanan, K. S. (2015) "Augmentation of mechanical and bond strength of coconut shell concrete using quarry dust," European Journal of Environmental and Civil Engineering 21(5), 629640. DOI: 10.1080/19648189.2016.1144540

Gunasekaran, K., Annadurai, R., Chandar, S. P., and Anandh, S. (2017). "Study for the relevance of coconut shell aggregate concrete non-pressure pipe," Ain Shams Engineering Journal 8(4), 523-530. DOI: 10.1016/j.asej.2016.02.011

Henrist, C., Mathier, J., Vogels, C., Rulmont, A., and Cloots, R. (2003). "Morphological study of magnesium hydroxide nanoparticles precipitated in dilute aqueous solution," Journal of Crystal Growth 249(1-2), 321-330. DOI: 10.1016/S0022-0248(02)02068-7

Husseinsyah, S., and Mostapha, M. (2011). "The effect of filler content on properties of coconut shell filled polyester composites," Malaysian Polymer Journal 6(1), 87-97.

Ikumapayi, O. M., and Akinlabi, E.T. (2019). "Image processing and particle size analysis of coconut shell nanoparticles," International Journal of Civil Engineering and Technology (IJCIET) 10(2), 2475-2482.

IS 456 (2000). "Plain and reinforced concrete - Code practice," Indian Standard, New Delhi, India.

IS 10262 (2019). “Concrete mix proportioning - Guidelines,” Indian Standard, New Delhi, India.

Jabatan Pertanian Sarawak (2009). "Coconut Industry Development Program (CIDP) 10th Malaysia Plan (10MP) mechanics and guideline," (https://doa.sarawak.gov.my/modules/web/download_show.php?id=920), Accessed 19 Aug 2020.

Kanojia, A., and Jain, S. K. (2015). "Performance of coconut shell as coarse aggregate in concrete: A review," International Research Journal of Engineering and Technology (IRJET) 2(4), 1096-1100. DOI: 10.1016/j.conbuildmat.2017.02.066

Kanojia, A., and Jain, S. K. (2017). "Performance of coconut shell as coarse aggregate in concrete," Construction and Building Materials 140(1), 150-156. DOI: 10.1016/j.conbuildmat.2017.02.066

Kumar, L., Li, W. Z., Vannoy, C. H., Leblanc, R. M., and Wang, D. (2009). "Synthesis, characterization and optical properties of $\mathrm{Mg}(\mathrm{OH})_{2}$ micro-/nanostructure and its conversion to $\mathrm{MgO}$," Ceramic International 35(8), 3355-3364. DOI: 10.1016/j.ceramint.2009.05.035

Lazim, Z. M., Hadibarata, T., Puteh, M. H., and Yusop, Z. (2015). “Adsorption characteristics of bisphenol A onto low-cost modified phyto-waste material in aqueous solution," Water, Air, \& Soil Pollution 226(34), 1-11. DOI: 10.1007/s11270015-2318-5

Leman, A. S., Shahidan, S., Senin, M. S., and Hannan, N. I. R. R. (2016). "A preliminary study on chemical and physical properties of coconut shell powder as a filler in concrete," IOP Conference Series: Materials Science and Engineering 160(1), 012059. DOI: 10.1088/1757-899X/160/1/012059

Matschei, T., Lothenbach, B., and Glasser, F. P. (2007). "The role of calcium carbonate in cement hydration," Cement and Concrete Research 37(4), 551-558. DOI: 10.1016/j.cemconres.2006.10.013

Meddah, M. S., Zitouni, S., and Belâabes, S. (2010). "Effect of content and particle size distribution of coarse aggregate on the compressive strength of concrete," Construction and Building Materials 24(4), 505-512. DOI:

10.1016/j.conbuildmat.2009.10.009 
National Ready Mixed Concrete Association (2003). "Structural lightweight concrete," (https://www.nrmca.org/aboutconcrete/cips/36p.pdf), Accessed 19 Aug 2020.

Nadir, Y., and Sijatha, A. (2017). "Durability properties of coconut shell aggregate concrete," Structural Engineering 22(1), 1920-1926. DOI: 10.1007/s12205-0170063-6

Olutoge, F. A. (2010). "Investigations on sawdust and palm kernel shells as aggregate replacement," ARPN Journal of Engineering and Applied Sciences 5(4), 7-13.

Oriol, M., and Pera, J. (1995). "Pozzolanic activity of metakaolin under microwave treatment," Cement and Concrete Research 25(2), 265-270. DOI: 10.1016/00088846(95)00007-0

Pappu, A., Saxena, M., and Asolekar, S. R. (2007). "Solid wastes generation in India and their recycling potential in building materials," Building and Environment 42(6), 2311-2320. DOI: 10.1016/j.buildenv.2006.04.015

Roa, K. V., Swaroop, A., Roa, K. R., and Bharath, N. (2015). "Study on strength properties of coconut shell concrete," International Journal of Civil Engineering and Technology 6(3), 42-61.

Sabih, A., Abdullah, A., and Aqeel, A. S. (2016). "Performance of waste coconut shell as partial replacement of natural coarse aggregate in concrete," International Journal of Scientific \& Engineering Research 7(8), 1802-1809.

Samiei, M., Janani, M., Vahdati, A., Alemzadeh, Y., and Bahari, M. (2017). "Scanning electron microscopy and energy-dispersive X-ray microanalysis of set CEM cement after application of different bleaching agents," Iranian Endodontic Journal 12(2), 191-195. DOI: 10.22037/iej.2017.37

Shahidan, S., Leman, A. S., Senin, M. S., and Hannan, N. I. R. R. (2016). "Suitability of coconut shell concrete for precast cool wall panel-A review," MATEC Web of Conferences 87(7), Article ID 01005. DOI: 10.1051/matecconf/20178701005

Shraddha, D., Hitali, F., Pradeep, D., and Varpe, S. (2014). "Sustainable concrete by partially replacing coarse aggregate using coconut shell," Journal on Today's Ideas Tomorrow's Technologies 2(1), 41-54. DOI: 10.15415/jotitt.2014.21004

Shubbar, A. A., Jafer, H., Abdulredha, M., Al-Khafaji, Z. S., Nasr, M. S., Al Masoodi, Z., and Sadique, M. (2020). "Properties of cement mortar incorporated high volume fraction of GGBFS and CKD from 1 day to 550 days," Journal of Building Engineering 30(1), Article ID 101327. DOI: 10.1016/j.jobe.2020.101327

Traore, Y. B., Messan, A., Hannawi, K., Gerard, J., Prince-Agbodjan, W., and Tsobnang, F. (2017). "Experimental investigations on the physical and mechanical properties of a lightweight concrete using oil palm shell as coarse aggregate," Journal of Materials Science and Engineering A 7(3), 157-168. DOI: 10.17265/2161-6213/2017.5-6.005

Trezza, M. A. (2007). "Hydration study of ordinary Portland cement in the presence of zinc ions," Materials Research 10(4), 331-334. DOI: 10.1590/S151614392007000400002

Wassilkowska, A., Czaplicka-Kotas, A., Bielski, A., and Zielina, M. (2014). “An analysis of the elemental composition of micro-samples using EDS technique," Czasopismo Techniczne: Chemia [Technical Transactions: Chemistry] 2014(1-Ch), 133-148. DOI: 10.4467/2353737XCT.14.283.3371

Wu, X., Hu, G., Wang, B., and Yang, Y. (2008). "Synthesis and characterization of superfine magnesium hydroxide with monodispersity," Journal of Crystal Growth 310(2), 457-461. DOI: 10.1016/j.jcrysgro.2007.10.025 
Yaacob, I. I., Ali, M.Y., Sopyan, L., and Hashmi, S. (2015). "Effect of calcium carbonate replacement on workability and mechanical strength of Portland cement concrete," Advanced Materials Research 1115, 137-141. DOI: 10.4028/www.scientific.net/AMR.1115.137

Yerramala, A., and Ramachandrudu, C. (2012). "Properties of concrete with coconut shells as aggregate replacement," International Journal of Engineering Inventions $1(6), 21-31$.

Yousuf, M., Mollah, A., Palta, P., Hess, T. R., Vempati, R. K., and Cocke, D. L. (1995). "Chemical and physical effects of sodium lignosulfonate superplasticizer on the hydration of Portland cement and solidification/stabilization consequences," Cement and Concrete Research 25(3), 671-682. DOI: 10.1016/0008-8846(95)00055-H

Yun, T. Z. (2019). “Agriculture: A coconut revival," The Edge Markets, (https://www.theedgemarkets.com/article/agriculture-coconut-revival), Accessed 19 Aug 2020

Article submitted: April 8, 2021; Peer review completed: July 11, 2021; Revised version received and accepted: July 14, 2021; Published: July 16, 2021.

DOI: 10.15376/biores.16.3.6057-6073 